\title{
DATING OF CAVES BY COSMOGENIC NUCLIDES: METHOD, POSSIBILITIES, AND THE SIEBENHENGSTE EXAMPLE (SWITZERLAND)
}

\author{
DATIRANJE JAM S KOZMOGENIMI NUKLIDI: \\ METODA, MOŽNOSTI IN PRIMER JAMSKEGA SISTEMA \\ SIEBENHENGSTE (ŠVICA)
}

PHILIPP HÄUSELMANN ${ }^{1,2} \&$ DARRYL E. GRANGER ${ }^{1}$

\footnotetext{
${ }^{1}$ Earth and Atmospheric Sciences, Purdue University, 1397 Civil Engineering Building, West Lafayette, IN 47907, USA

2 Institut für Angewandte Geologie, Universität für Bodenkultur, Peter Jordan Str. 70, A-1190 Wien, Austria, praezis@geo.unibe.ch
}

Prejeto / received: 29.11.2004 


\begin{abstract}
UDC $539.16: 552.5$ (494)

Philipp Häuselmann \& Darryl E. Granger: Dating of caves by cosmogenic nuclides: method, possibilities, and the Siebenhengste example

Cosmic rays produce nuclides at and near the Earth's surface. ${ }^{10} \mathrm{Be}$ and ${ }^{26} \mathrm{Al}$ in quartz are of particular interest for dating cave sediments. These two nuclides are produced at the surface at a fixed ratio. If the quartz is carried from the surface into a cave, the sediment is shielded from additional cosmogenic nuclide production, and the inherited ${ }^{10} \mathrm{Be}$ and ${ }^{26} \mathrm{Al}$ decay radioactively. Because ${ }^{26} \mathrm{Al}$ decays more rapidly than ${ }^{10} \mathrm{Be}$, the ratio of these two nuclides indicates the time since the sediment was washed underground. The burial dating method can be applied to sediments in the age range of approximately 0.1 to $5 \mathrm{Ma}$. In ideal cases, we get information about valley lowering rates. If the provenance of the sediment is known, averaged erosion rates of the source area can be estimated. The oldest cave phases of the Siebenhengste system, Switzerland, were dated using cosmogenic nuclides. The oldest sediment is $4.4 \pm 0.6 \mathrm{Ma}$ and thus indicates Pliocene karstification of the Siebenhengste. Key words: cosmogenic nuclides, cave dating, methodology, Siebenhengste, Switzerland.
\end{abstract}

Izvleček:

UDK $539.16: 552.5(494)$

\title{
Philipp Häuselmann \& Darryl E. Granger: Datiranje jam z kozmogenimi nuklidi: metoda, možnosti in primer jamskega sistema Siebenhengste (Švica)
}

Kozmični žarki povzročajo nastanek kozmogenih nuklidov na površini zemlje in tik pod njo. Za datiranje jamskih sedimentov sta posebej pomembna ${ }^{10} \mathrm{Be}$ in ${ }^{26} \mathrm{Al}$, ki nastajata v kremenu. Ko je kamen na površini in izpostavljen kozmičnemu sevanju, nastajata v stalnem razmerju. Ko ga zanese v podzemlje, se tvorba kozmogenih nuklidov ustavi, nadaljuje pa se njihov radioaktivni razpad. $\mathrm{Ker}^{26} \mathrm{Al}$ razpada hitreje, lahko iz razmerja med njima izračunamo čas, ki je potekel odkar je kremen pod zemljo. Metodo lahko uporabimo na sedimentih, ki so pokopani oziroma $\mathrm{v}$ jami med 0.1 in 5 milijoni let. Na ta način lahko v idealnih primerih izračunamo hitrost vrezovanja dolin. Z opisano metodo smo določili starost najstarejših delov sistema Siebenhengste v Švici. Najstarejši sediment je star $4.4 \pm 0.6 \mathrm{Ma}$ in nakazuje, da je na tem območju potekalo zakrasevanje že v pliocenu.

Ključne besede: kozmogeni nuklidi, datiranje jam, metodologija, Siebenhengste, Švica . 


\section{INTRODUCTION}

Cosmogenic nuclides are generated by the interaction of cosmic rays (mainly protons, neutrons, and muons) with atoms in the Earth's atmosphere and lithosphere. A huge variety of stable and radioactive cosmogenic nuclides is produced. For example, one of the most widely known cosmogenic nuclide is ${ }^{14} \mathrm{C}$ that is produced in the atmosphere. In this paper, we focus on ${ }^{10} \mathrm{Be}$ and ${ }^{26} \mathrm{Al}$ that are produced within quartz mineral grains near the ground surface.

The production rate of cosmogenic isotopes depends on the intensity of the cosmic rays, which is subject to change. In particular, the incoming intensity of the rays changes with solar and stellar activity (Lal \& Peters 1967). The magnetic field of the Earth (which changes also) diverts low-energy particles from low latitudes, causing production rates to be latitude-dependent. The atmosphere absorbs most of the primary rays and thus causes production rates to depend on elevation. Finally, the geometry of the sample location (and eventual snow or soil cover) also has its effects. Thus, the production rate at a given site is latitude, altitude and climate dependent, subject to change within time, and therefore difficult to determine exactly. However, models and calculations (Stone 2000; Masarik et al. 2000) permit estimation of the production rate to within approximately $10 \%$.

The most widely used radioactive nuclides are ${ }^{10} \mathrm{Be}$ and ${ }^{26} \mathrm{Al}$ produced in Quartz. This mineral is preferred because of its simple chemical composition, its tight lattice, and its resistivity to chemical attacks (Lal \& Arnold 1985). ${ }^{10} \mathrm{Be}$ has been used for several years now for the determination of the surface exposure age, that is the time since the respective rock was brought to the surface. The applications for that technique are mainly dating boulders on glacial moraines, surfaces exposed by landslides, and surfaces eroded by glaciers (Gosse \& Phillips 2001).

\section{THE PRINCIPLE AND POSSIBILITIES OF BURIAL DATING}

Burial Dating of cave sediments is a relatively new technique that indicates the time sediment has been underground (Granger et al. 2001). It relays on the radioactive decay of the nuclides that were previously accumulated when the sediment was exposed at the surface. Whereas the intensity of the cosmic rays may vary with time, the ratio of produced $10 \mathrm{Be}$ to $26 \mathrm{Al}$ remains always approximately 1:6.8. The ${ }^{10} \mathrm{Be} /{ }^{26} \mathrm{Al}$ ratio can thus be calculated from the production rates and radioactive decay. If a sample that contains ${ }^{10} \mathrm{Be}$ and ${ }^{26} \mathrm{Al}$ is washed underground to sufficient depth to be shielded from further radiation, the nuclide concentrations diminish. Since ${ }^{26} \mathrm{Al}$ has a half-live of $720 \mathrm{ka}$, opposed to the one of ${ }^{10} \mathrm{Be}$ of $1.34 \mathrm{Ma}$, the ratio of 1:6.8 is gradually lowered. Measurement of that ratio therefore gives a direct indication of the time the sample remained underground.

Of course, several prerequisites have to be fulfilled in order to get a burial age:

- First of all, the sediment must contain quartz that was irradiated sufficiently prior to burial. The grain size should be minimally fine sand (otherwise the cleaning process also eliminates the quartz), but may reach pebble size without problem.

- Then, burial should ideally be 20-30 m below the surface. Muons still reach that depth, but the production rate is very small and can be ignored for most samples.

- In order to make a measurement meaningful, the stratigraphic relationship of the sampled sand with the passage and other sediments should be clearly established. Sand is mobile, thus the danger persists that a sample was removed from the surface several million years ago, and transported to the present site only recently. However, experience has shown that this is a very 


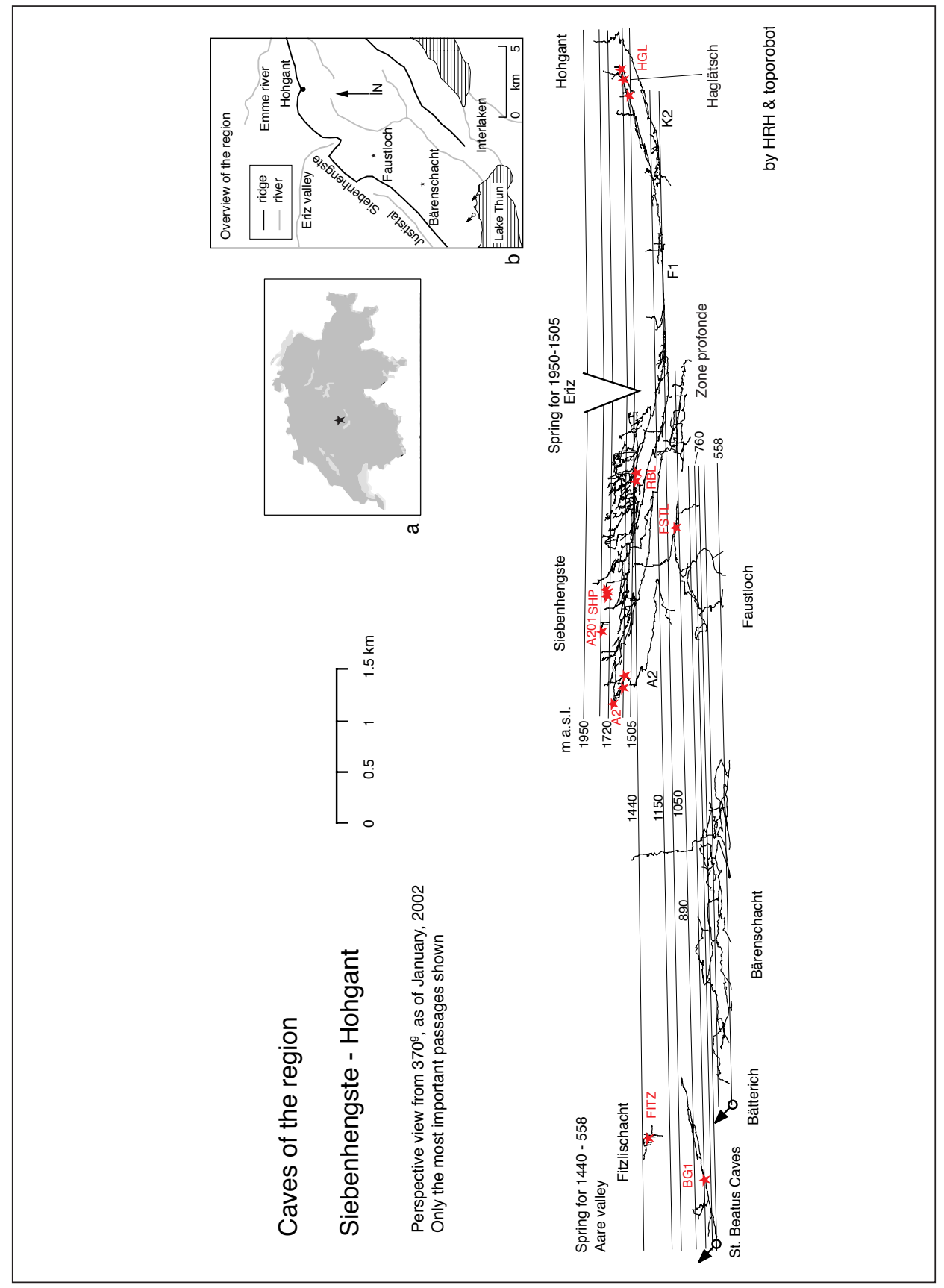

Fig. 1: Projection (370g) of the Siebenhengste caves with the speleogenetic phases. Stars indicate sampling places for cosmogenic dates. 
rare case. The opposite case, deposition of recent sand in an old passage, is seen more often. In that case, the age determination gives the depositional age of the sand, but only a minimum age of the passage.

Burial Dating has a range from about 100,000 years up to $5 \mathrm{Ma}$. After that time, the amount of remaining isotopes is usually too small to be measured accurately (Granger \& Muzikar 2001). It is one of only a few radiometric methods that date lower Quarternary and Pliocene deposits. It is of great interest for cave dating, first because many old caves were created in the Pliocene or even earlier, and second because caves are very effective at shielding the sediment from further cosmic ray bombardment. As with other cave-dating methods, burial dating may also be used to date the age of the passage, thus indicating valley deepening rates and evolution of the surface outside the cave. Moreover, backward modeling of the amount of nuclides present prior to burial (coupled with local production rate estimates) indicates erosion rates at the source area - a rate that usually is not obtainable by cave data and which can be very valuable for constraining landscape evolution.

\section{THE SIEBENHENGSTE EXAMPLE}

We used burial dating to date the old passages of the Siebenhengste cave system in Switzerland. The Siebenhengste region is situated in the north-western part of the Alps, adjacent to the molasse basin. From Lake Thun, the mountain range extends to the Schrattenfluh, $20 \mathrm{~km}$ away. The cave region is one of the longest and deepest worldwide, with the Réseau Siebenhengste-Hohgant having $150 \mathrm{~km}$ length and $-1340 \mathrm{~m}$ depth. All caves in the region sum up to $290 \mathrm{~km}$ of galleries that often

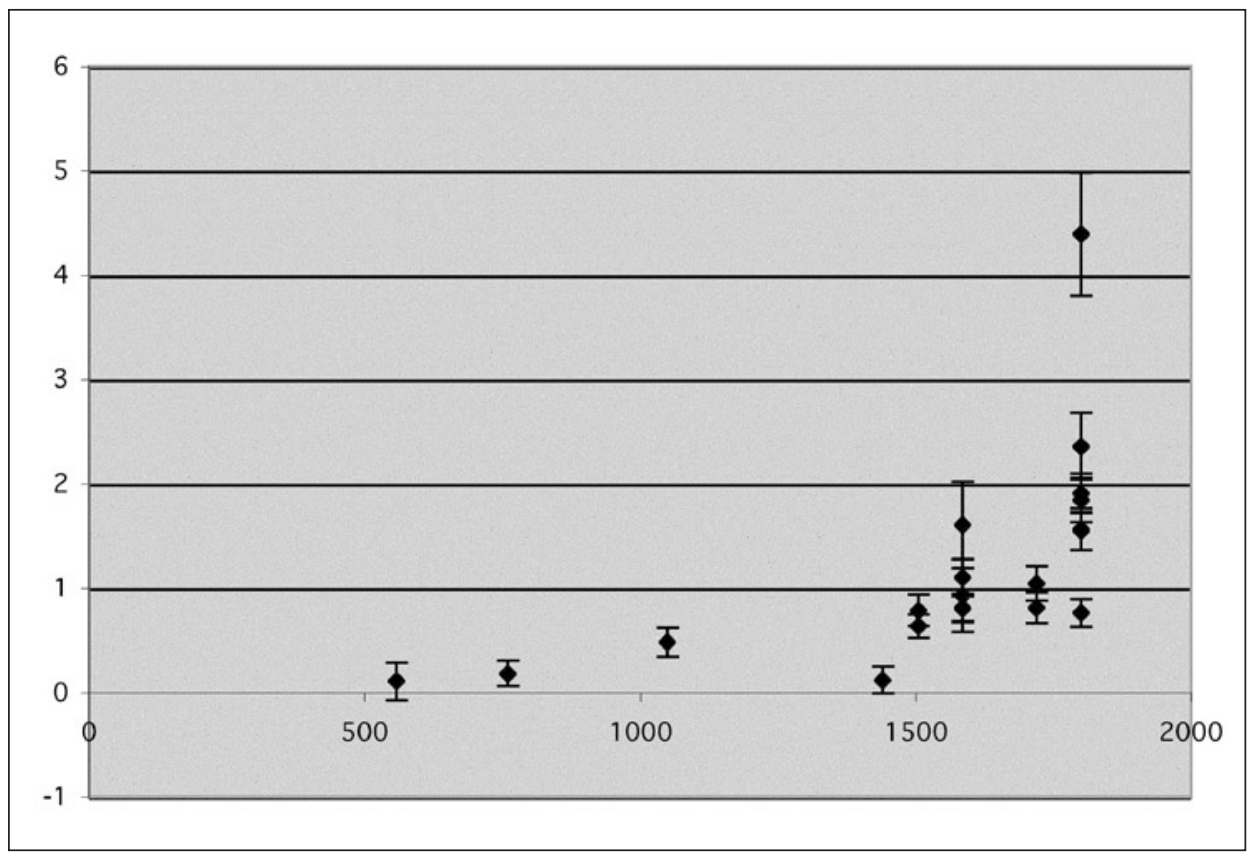

Fig. 2: Plot of ages (vertical) versus altitude (horizontal). 
form a very complicated network. The caves comprise 14 different speleogenetic phases, which can be related to paleovalley bottoms (Jeannin et al. 2000). The highest and oldest five phases (at presumed spring elevations of $>1900,1800,1720,1585$, and $1505 \mathrm{~m}$ a.s.l.) had their springs in the Eriz valley (Fig. 1). The next phase, at $1440 \mathrm{~m}$, shows a change in flow direction of $180^{\circ}$. The spring was then located in the area of Lake Thun. The influence of today's Aare valley (the site of Lake Thun today) therefore became predominant. All subsequent springs (at 1145, 1050, 890, 805, 760, 700, 660, and $558 \mathrm{~m}$ a.s.1.) drained towards the Aare valley.

In the area between Lake Thun and Hohgant, a total of 23 sites were sampled (see Fig. 1: stars indicate sites). Among those, 21 were selected for analysis. Quartz from the sample was purified by selective chemical dissolution, dissolved in $\mathrm{HF}$, and spiked with about $0.7 \mathrm{mg}{ }^{9} \mathrm{Be}$. $\mathrm{Al}$ and Be were separated and purified by ion chromatography and selective precipitation. The precipitates were dried, oxidized and mixed with metal powder for accelerator mass spectrometry (AMS), conducted

\begin{tabular}{|l|r|r|l|}
\hline Sample & Elevation & age & error \\
\hline SHP7 & 1800 & 4.39 & 0.59 \\
\hline SHP2 & 1800 & 2.36 & 0.32 \\
\hline A201 & 1800 & 1.91 & 0.19 \\
\hline SHP5 & 1800 & 1.84 & 0.21 \\
\hline SHP1 & 1800 & 1.57 & 0.20 \\
\hline SHP6 & 1800 & 1.55 & 0.18 \\
\hline SHP4 & 1800 & 0.76 & 0.13 \\
\hline HGLS & 1720 & 1.05 & 0.16 \\
\hline A2TR & 1720 & 0.81 & 0.15 \\
\hline HGLP & 1585 & 1.61 & 0.41 \\
\hline L18 & 1585 & 1.10 & 0.18 \\
\hline HGLT & 1585 & 0.93 & 0.35 \\
\hline A2NS & 1585 & 0.81 & 0.14 \\
\hline A2CHU & 1585 & 0.80 & 0.12 \\
\hline RBL2 & 1505 & 0.78 & 0.15 \\
\hline RBL1 & 1505 & 0.64 & 0.11 \\
\hline FITZ & 1440 & 0.12 & 0.13 \\
\hline FSTL & 1050 & 0.48 & 0.14 \\
\hline BG1 & 760 & 0.18 & 0.12 \\
\hline MWA & 558 & 0.11 & 0.18 \\
\hline
\end{tabular}

Table 1: The results of the dating. The elevation is in $m$ above sea level, the dates are in million years. 
at Lawrence Livermore National Laboratory (California, USA). Stable aluminium concentrations were determined by atomic absorption spectrophotometry. Cosmogenic nuclide production rates were assumed constant; since the uplift of the Alps in the particular place is not quantifiable, a mean source altitude of $1700 \mathrm{~m}$ was assumed. Our stated errors are 1 sigma and are calculated from AMS and AAS uncertainites only. There remains an ambiguity in the half-life of ${ }^{10} \mathrm{Be}$ (Partridge et al. 2003, p. 612); here we use the value of $1.34 \mathrm{Ma}$. Thus the initial production ratio of $\mathrm{Al}: \mathrm{Be}$ is 6.8 instead of around 6 as in other publications.

The results show a great diversity of ages, ranging from $118 \mathrm{ka}$ up to $4.4 \mathrm{Ma}$ (Table 1). The surface sample (MWA) has a burial age of $106 \pm 176 \mathrm{ka}$. Thus, the value is indistinguishable from zero, and we may assume that the sample was never buried. The sample from St. Beatus Cave (BG1) has an age of $182 \pm 122 \mathrm{ka}$. Its true value, bracketed by U/Th ages, should be between 160 and $235 \mathrm{ka}$, which is again the case. These values indicate that the method yields young ages where expected.

A difficulty for dating with cosmogenic nuclides is mobility of the sediment. For instance, recent sand can be transported into a fossilized cave by a flood and then be deposited. Our results show that this process happens: for any speleogenetic phase, there is a range of ages observed (Fig. 2). However, Fig. 2 also indicates that the re-mobilization and re-deposition of old sediments is rarely observable: if this would be the case, we would expect a random distribution of ages throughout the phases. However, the maximum age decreases with the next lower phase. We can thus assume a gradual valley lowering with time, as indicated by the envelope of the data.

Close observation of Fig. 2 indicates a knickpoint in the line connecting the maximum ages: this knickpoint occurs at around $800 \mathrm{ka}$ and $1500 \mathrm{~m}$. This point reflects a dramatic increase in valley deepening rate and coincides with the change in flow direction from Eriz to the Aare valley.

\section{CONCLUSIONS}

Burial age dating by cosmogenic nuclides is proven to be a powerful tool for ages between $200 \mathrm{ka}$ and $5 \mathrm{Ma}$. The results presented here are the first cosmogenic dates for an Alpine cave system in a glacially influenced area. The results indicate an onset of karstification in the Siebenhengste before 4.4 Ma, that is in the Pliocene or even earlier. The dates obtained show a continuous valley deepening with time; together with U/Th dates obtained earlier (Häuselmann 2002), the history of the Siebenhengste cave system and its surrounding environment can be traced over a huge timespan.

The study of old cave systems will benefit from absolute cosmogenic datings; if speleogenetic phases can be related to the overall geomorphic evolution of an area, the rate, duration, and extent of valley deepenings can be assessed. Further studies will greatly enhance our understanding of the geomorphic evolution of the Alps and surrounding areas in the last 5 million years.

\section{ACKNOWLEDGMENTS}

First thanks go to the cavers, whose interminable mapping makes it possible to conduct such studies. PH acknowledges DG, Amy Wolkowinsky and Tom Clifton for personal as well as laboratory support in difficult times. The project was funded by the Swiss National Science Foundation via Forschungskommission Universität Freiburg (Grant No. 81FR-68830) and the United States National Science Foundation (NSF-EAR 0092459). A review of Art Palmer improved the manuscript. 


\section{REFERENCES}

Gosse, J.C. \& F.M. Phillips, 2001: Terrestrial cosmogenic nuclides: theory and applications. - Quat Sci Rev, 20, 1475-1560.

Granger, D.E., D. Fabel \& A.N. Palmer, 2001: Pliocene-Pleistocene incision of the Green River, Kentucky, determined from radioactive decay of cosmogenic 26Al and 10Be in Mammoth Cave sediments. - GSA Bulletin, 113, 7, 825-836.

Granger, D.E. \& P.F. Muzikar, 2001: Dating sediment burial with in-situ produced cosmogenic nuclides: theory, techniques, and limitations. - Earth Planet Sci Letters, 188, 269-281.

Häuselmann, Ph., 2002: Cave Genesis and its relationship to surface processes: Investigations in the Siebenhengste region (BE, Switzerland). - PhD thesis, University of Fribourg Switzerland, $168 \mathrm{p}$.

Jeannin, P.-Y., T. Bitterli \& Ph. Häuselmann, 2000: Genesis of a large cave system: the case study of the North of Lake Thun system (Canton Bern, Switzerland). - in: Klimchouk, Ford, Palmer, Dreybrodt (Eds.), Speleogenesis: Evolution of Karst Aquifers, NSS, 2000, 338-347.

Lal, D. \& B. Peters, 1967: Cosmic ray produced radioactivity on the Earth. In: Flugge (Ed.), Handbuch der Physik, Berlin, Springer Verlag, 551-612.

Lal, D. \& J.R.Arnold, 1985: Tracing quartz through the environment. - Indian Acad Sci Proc, Earth and Planetary Science, 94, 1-5.

Masarik, J., D. Kollar \& S. Vanya, 2000: Numerical simulation of in-situ production of cosmogenic nuclides: Effects of irradiation geometry. - Nucl Instr and Meth in Phys Res B, 172, 786789.

Partridge, T.C., D.E. Granger, M.W. Caffee \& R.J. Clarke, 2003: Lower Pliocene hominid remains from Sterkfontein. - Science, 300, 607-612.

Stone, J.O., 2000: Air pressure and cosmogenic isotope production. - J Geophys Res, 105, B10, 23753-23759. 